\title{
Comparison of urban residential storm water runoff quality in Bucharest, Romania with international data
}

\author{
Dan Rădulescu, ${ }^{1, *}$, Gabriel Racovițeanu ${ }^{1}$ and Xavier Swamikannu ${ }^{2}$ \\ ${ }^{1}$ Hydrotechnical Engineering Department, Technical University of Civil Engineering, Bucharest, Romania \\ ${ }^{2}$ Environmental Sciences and Engineering Program, University of California, Los Angeles, California, USA
}

\begin{abstract}
Diffuse pollution is a major source of contaminants to surface waters in urban areas. Land use activities and the degree of imperviousness have a strong influence on the pollutant loadings and the pattern and distribution of the pollutograph. Uncontrolled discharges of contaminated urban storm water runoff contribute to impairments of water quality in receiving waters. In this study, grab samples of storm water runoff were collected from a small high-density residential catchment area in Bucharest. The pollutant concentrations were analysed for several water quality physical and chemical parameters including $\mathrm{pH}$, conductivity, oil and grease, nutrients, pathogen indicator bacteria and some heavy metals. The storm events were monitored through grab sampling. The sample results for this representative residential catchment area in Bucharest were then compared with data reported from other regions of the world. The analysis demonstrates that the characteristics of the urban runoff quality from residential areas in Bucharest were comparable with data obtained from other areas in the world.
\end{abstract}

\section{Introduction}

Significant progress has been made worldwide in the treatment of municipal wastewater to protect public health and improve water quality of streams, rivers, and coastal waters. This progress is the result of major investments in the wastewater conveyance and treatment infrastructure, advancements in treatment technologies, better training of personnel and improvements in systems operations and maintenance. Despite these advancements and achievements, research studies first performed in the 1970's in the United States [1] and other parts of the world revealed that municipal storm water runoff conveyed through separate storm sewers and combined sewer overflows during storm events resulted in the discharge of untreated contaminated stormwater runoff into receiving waters. As a result of these uncontrolled discharges of municipal storm water runoff the United States Congress amended the Clean Water Act and adopted the Water Quality Act of 1987 to specifically address discharges of industrial and municipal storm water. The U.S. Congress recognized that "runoff from municipal separate storm sewers and industrial sites contains significant volumes of both toxic and conventional pollutants." [2]

A recent study [3] performed for the European Commission to assess the impact of storm water overflows from combined waste water collecting systems on water bodies (including the marine environment) in the 28 European Union member states identified a number of areas where additional steps must be taken to "improve the knowledge base and better assess the impacts of storm water overflows: a) better understanding of the impact of storm water overflows on the quality of the receiving water body; b) better assessment of health risks, based on the exposure of human activities to contaminated water; c) an approach to monitor storm water overflows."

In addition, presently, the adverse impacts of climate change are obvious, and these are a constant reminder that we must adapt our paradigm of managing water resources, especially in the urban environment, to more holistically integrate multiple environmental aspects that include urban storm water runoff. Extreme storm events such as that which occurred recently in Ellicott City, Maryland, when consecutive " 1 in a 1,000 -year" storm events happened in a span of two years, portend a drastically changing climate [4] with the potential for devastating consequences if unprepared. At the European Union level there is recognition that "[i]n the future, the impacts of storm water overflows could be influenced by several factors: climate change, which is expected to bring higher temperatures in Europe and higher rainfall in parts of the $\mathrm{EU}$, as well as contribute to the reduction of river streams during the summer season, which will result in higher storm water overflow impacts; ongoing urban development, which is created more paved areas, resulting in higher rates of run-off and thus greater risks of storm water overflows; and emerging diseases, including diseases such as malaria whose occurrence in Europe may increase with climate change."[3]

Previous international studies have identified imperviousness as a major indicator for impacts of urbanization on small streams and receiving waters [5-9]. According to one study [5] the impacts can be detected in four broad categories: changes in hydrologic, physical, water quality or biological indicators. Other studies linked percentage imperviousness to biotic stream characteristics, and water quality with the percentage of land cover [8]. It

\footnotetext{
*Corresponding author: dan.radulescu@utcb.ro
} 
is essential to conduct an inventory and identify the various urban land uses characteristics in order to develop an effective storm water management strategy to control sources of pollution and changes in the storm water runoff quantity [6]. Atmospheric deposition may also be an important source of pollutants to urban storm water runoff, including heavy metals, organics and microorganisms [1012]. The major groups of pollutants detected in urban stormwater may be categorized as [13]:

- $\quad$ Total suspended solids (TSS);

- Heavy metals;

- $\quad$ Polycyclic aromatic hydrocarbons (PAHs);

- Nutrients;

- Pathogens.

Imperviousness is a leading indicator for adverse water quality impacts, the higher the extent of imperviousness the higher is the level of impacts [9]. It is important to understand the complexity of the causes and detailed studies must focus on the specifics for each factor including hydrological, physical, water quality and biological impacts.

The Nationwide Urban Runoff Program (NURP) [1] conducted between 1978 and 1983 at 81 specific sites was one of the first studies conducted at a national level to identify sources and pollutants in urban storm water runoff. Much of the NURP data was obtained from urban residential area. The study concluded that heavy metals, especially copper, lead, and zinc are the most common pollutants found in urban storm water runoff. The concentrations for the metals in end-of-pipe urban runoff samples (undiluted by receiving waters) exceeded U.S. Environmental Protection Agency's (USEPA) water quality criteria and drinking water standards often [1]. For the NURP study, the event mean concentration, defined as the total constituent mass discharge divided by the total runoff volume, was chosen as the primary water quality measurement. Based on the NURP data set values, expressed as site median EMC values for the median urban site, the following select constituent results are summarized in Table 1.

Table 1. Event mean concentration median values for select heavy metals, nutrients and oxygen demanding substances.

\begin{tabular}{|l|c|}
\hline \multicolumn{1}{|c|}{ Constituent } & EMC (expressed as total) \\
\hline $\mathrm{Cu}$ & $34 \mu \mathrm{g} / \mathrm{l}$ \\
\hline $\mathrm{Pb}$ & $144 \mu \mathrm{g} / \mathrm{l}$ \\
\hline $\mathrm{Zn}$ & $160 \mu \mathrm{g} / \mathrm{l}$ \\
\hline Total Phosphorus & $0.33 \mathrm{mg} / \mathrm{l}$ \\
\hline Soluble Phosphorus & $0.12 \mathrm{mg} / \mathrm{l}$ \\
\hline Total Kjeldahl $\mathrm{N}$ & $1.5 \mathrm{mg} / \mathrm{l}$ \\
\hline $\mathrm{NO}_{2+3} \mathrm{~N}$ & $0.68 \mathrm{mg} / \mathrm{l}$ \\
\hline $\mathrm{BOD}_{5}$ & $9 \mathrm{mg} / \mathrm{l}$ \\
\hline $\mathrm{COD}$ & $65 \mathrm{mg} / \mathrm{l}$ \\
\hline
\end{tabular}

The NURP study concluded that organic pollutants were detected at a lower frequency and lower concentrations than the heavy metals. In addition, coliform bacteria was present at high levels with the median faecal coliform counts for all sites being around $21 \times 10^{3} / 100 \mathrm{ml}$. Nutrients were generally detected in urban runoff, however, concentrations did not appear to be extremely high. As for oxygen-demanding substances, the same study concluded that these compounds were present in urban runoff at concentrations close to those in secondary treatment plant discharges. Furthermore, total suspended solids concentrations were considered high in comparison with treatment plant discharges, and the composition of the urban sediments posed serious concerns due to the ability to have other contaminants adsorbed to them.

About the same time as NURP, other research studies conducted to determine the characteristics of urban storm water runoff and its effects on the receiving waters [14]. A review of the studies available at that time revealed a range of values for several parameters, as shown in Table 2.

Table 2. The range of concentration in urban storm water.

\begin{tabular}{|c|c|}
\hline Parameter & Low $\quad-\quad$ High \\
\hline $\mathrm{BOD}_{5}$ & $1-700 \mathrm{mg} / \mathrm{l}$ \\
\hline TOC & $1-150 \mathrm{mg} / \mathrm{l}$ \\
\hline COD & $5-3,100 \mathrm{mg} / \mathrm{l}$ \\
\hline Suspended Solids & $2-11,300 \mathrm{mg} / \mathrm{l}$ \\
\hline Settleable Solids & $0.5-5,400 \mathrm{mg} / \mathrm{l}$ \\
\hline Organic N & $0.01-16 \mathrm{mg} / 1$ \\
\hline Total Kjeldahl N & $0.01-4.5 \mathrm{mg} / \mathrm{l}$ \\
\hline $\mathrm{NH}_{3} \mathrm{~N}$ & $0.1-2.5 \mathrm{mg} / \mathrm{l}$ \\
\hline $\mathrm{NO}_{3} \mathrm{~N}$ & $0.01-1.5 \mathrm{mg} / \mathrm{l}$ \\
\hline Soluble $\mathrm{PO}_{4}$ & $0.1-10 \mathrm{mg} / \mathrm{l}$ \\
\hline Total $\mathrm{PO}_{4}$ & $0.1-125 \mathrm{mg} / \mathrm{l}$ \\
\hline Oils & $0-110 \mathrm{mg} / \mathrm{l}$ \\
\hline Lead & $0-1.9 \mathrm{mg} / \mathrm{l}$ \\
\hline Total Coliforms & $200-150 \times 10^{6} / 100 \mathrm{ml}$ \\
\hline Faecal Coliforms & $55-110 \times 10^{6} / 100 \mathrm{ml}$ \\
\hline Faecal Streptococci & $200-1.2 \times 10^{6} / 100 \mathrm{ml}$ \\
\hline Chlorides & $2-25,000 \mathrm{mg} / \mathrm{l}^{*}$ \\
\hline
\end{tabular}

More recent studies have focused on the specific contribution of contaminants from urban land uses to receiving waters. The aim was to better characterize the sources of pollution and to identify the most effective storm water controls to be implemented. One of these studies [15], at land use sites in Los Angeles, in the Southern California region, confirmed that residential areas contribute significant pollutant loads. A high density residential area is considered, in general, an area which have been zoned for a high density of single-family homes, condominiums, townhouses, low, medium, and multistory apartment buildings.

The National Stormwater Quality Database (NSQD) is a USEPA initiated effort to compile stormwater quality data in the U.S. in a standardized format and provide easy access to researchers and other interested persons. It includes the monitoring results of the U.S. regulatory program for urban communities (municipal separate storm sewer systems covered by storm water discharge permits), the National Urban Runoff Program (NURP), a portion of the International Stormwater BMP Database, and special projects that have been added since 2001 [16]. Only data from separate storm water system outfall locations were entered in the database. It is interesting to note that the values found in the NSDQ represent event mean concentrations, which allows comparisons to previous data, and the coefficient of variation is between 1.0 to 2.0 across all land uses investigated, for the majority of 
pollutants. Furthermore, the residential land use has the most number of values in the database. The same research concluded that when comparing NURP and NSDQ data it appears that the differences were all within the normal range of variations for storm water quality, with a lower, in general, set of values in the more recent data, except for lead, which decreased by a factor of four [17]. This decrease is generally attributed to the elimination of lead as an additive in the gasoline sold in the United States. The phaseout of lead in gasoline began in 1974 when the USEPA introduced rules requiring the use of unleaded gasoline in new cars equipped with catalytic converters, and in 1995 a total ban of leaded gasoline came into effect [18].

An update of the analysis of the information found in NSDQ was presented in a more recent report [19]. Since the first compilation of data more information has been added in the database, however, given that much of the data are from residential land use areas, the data set is very robust, and any effect of new data and inferences is minimal.

Further research on storm water quality for residential land use was done in Los Angeles, California [20]. The results presented in Table 3 tend to confirm the temporal comparability of the data, with other studies, and the declining trend in lead concentration values in urban storm water runoff. The data confirms the decrease in lead pollution since the first studies were performed, by an order of magnitude, while for the other constituents the values remain more or less the same.

Table 3. Comparison of NURP and NSDQ to trace metals concentrations from specific land uses in the Los Angeles, California, USA.

\begin{tabular}{|l|c|c|c|}
\hline Land use type & \multicolumn{3}{|c|}{ Constituent Median EMC $(\boldsymbol{\mu g} / \mathbf{l})$} \\
\hline Residential & Total $\mathrm{Cu}$ & Total $\mathrm{Pb}$ & Total $\mathrm{Zn}$ \\
\hline LARW [21] & 18 & 8 & 103 \\
\hline NSDQ [18] & 16 & 17 & 117 \\
\hline NURP [1] & 33 & 144 & 135 \\
\hline
\end{tabular}

Studies performed elsewhere [21], in an urban catchment with rapid urbanization, demonstrate similar water quality characteristics. Sampling results obtained from two storm events in a catchment zone of residential high-density single story link houses are presented in Table 4.

Table 4. EMCs of constituents investigated in Miri, Sarawak.

\begin{tabular}{|c|c|c|c|c|c|}
\hline & \multicolumn{5}{|c|}{ EMCs of pollutants investigated } \\
\hline Events & $\begin{array}{c}\text { TSS } \\
(\mathrm{mg} / \mathrm{l})\end{array}$ & $\begin{array}{c}\mathrm{BOD}_{5} \\
(\mathrm{mg} / \mathrm{l})\end{array}$ & $\begin{array}{c}\mathrm{COD} \\
(\mathrm{mg} / \mathrm{l})\end{array}$ & $\begin{array}{c}\mathrm{NH}_{3}-\mathrm{N} \\
(\mathrm{mg} / \mathrm{l})\end{array}$ & $\begin{array}{c}\mathrm{Pb} \\
(\mathrm{mg} / \mathrm{l})\end{array}$ \\
\hline 1 & 158 & 10 & 135 & 2.17 & 0.36 \\
\hline 2 & 115 & 7 & 44 & 0.89 & 0.02 \\
\hline
\end{tabular}

A total of 18 rain events were sampled in a tropical urban residential catchment with an estimated $85 \%$ impervious area [22]. Storm water was grab sampled and the study's goal was to investigate the first flush phenomenon from residential, commercial and industrial basins. The statistical summary of EMCs of select pollutants from this study is shown in Table 5.
Research performed in an area characteristic for a cold climate in Northern Europe [23] also indicates that pollutant concentrations fall within the range of values similar to studies performed elsewhere in the world. To summarize the local storm water quality data collected in two multi-year studies on urban watersheds in Finland, the author used site mean concentrations (SMCs) values as a metric to compare sites in terms of a median value based on the EMCs. Data is shown in Table 6.

Table 5. Statistical summary of various pollutants at the residential catchment.

\begin{tabular}{|l|c|c|c|c|}
\hline \multirow{2}{*}{ Parameter } & \multicolumn{4}{|c|}{ EMC (mg/l) } \\
\cline { 2 - 5 } & Min & Max & Mean & Median \\
\hline TSS & 2 & 58 & 27 & 26 \\
\hline $\begin{array}{l}\text { Oil and } \\
\text { grease }\end{array}$ & 0.79 & 5.50 & 2.63 & 2.28 \\
\hline $\mathrm{BOD}$ & 1.6 & 21.3 & 8.1 & 6.5 \\
\hline $\mathrm{COD}$ & 14.9 & 147.4 & 45.1 & 38.7 \\
\hline $\mathrm{NO}_{3}-\mathrm{N}$ & 0.351 & 2.470 & 0.990 & 0.937 \\
\hline $\mathrm{NH}_{3}-\mathrm{N}$ & 0.018 & 2.385 & 0.408 & 0.174 \\
\hline $\mathrm{NO}_{2}-\mathrm{N}$ & 0.003 & 0.088 & 0.016 & 0.008 \\
\hline $\mathrm{TP}$ & 0.09 & 1.75 & 0.50 & 0.41 \\
\hline $\mathrm{Zn}$ & 0.01 & 0.14 & 0.06 & 0.05 \\
\hline
\end{tabular}

Table 6. Urban average pollutant concentration - Finnish datasets.

\begin{tabular}{|l|c|c|c|c|c|}
\hline & \multicolumn{5}{|c|}{ SMC values } \\
\hline $\begin{array}{l}\text { Land } \\
\text { use }\end{array}$ & $\begin{array}{c}\text { Suspended } \\
\text { Solids } \\
(\mathrm{mg} / \mathrm{l})\end{array}$ & $\begin{array}{c}\mathrm{Pb} \\
(\mu \mathrm{g} / \mathrm{l})\end{array}$ & $\begin{array}{c}\mathrm{Zn} \\
(\mu \mathrm{g} / \mathrm{l})\end{array}$ & $\begin{array}{c}\mathrm{Cu} \\
(\mu \mathrm{g} / \mathrm{l})\end{array}$ & $\begin{array}{c}\mathrm{Ni} \\
(\mu \mathrm{g} / \mathrm{l})\end{array}$ \\
\hline $\mathrm{MFR}^{1}$ & 156.71 & 11.40 & 231.89 & 34.24 & 11.71 \\
\hline
\end{tabular}

${ }^{1}$ Multi-family residential

Storm water runoff samples were collected in central Shanghai, China, during three storm events, from four land use areas: traffic, residential, commercial and industrial [24]. The aim of the research was to determine the EMCs of three species of nitrogen and the temporal variations of total phosphorus to assess the effects of urban runoff from different land uses on the quality of receiving waters, and the results are presented in Table 7.

Table 7. EMC values of pollutants in runoff samples collected from residential areas in Shanghai, China.

\begin{tabular}{|c|c|c|c|c|}
\hline Event & $\begin{array}{c}\mathbf{N H}_{4}{ }^{+}-\mathbf{N} \\
(\mathbf{m g} / \mathbf{l})\end{array}$ & $\begin{array}{c}\mathbf{N O}_{3}-\mathbf{N} \\
(\mathbf{m g} / \mathbf{l})\end{array}$ & $\begin{array}{c}\mathbf{N O}_{2}-\mathbf{N} \\
(\mathbf{m g} / \mathbf{l})\end{array}$ & $\begin{array}{c}\mathbf{T P} \\
(\mathbf{m g} / \mathbf{l})\end{array}$ \\
\hline 1 & 2.38 & 0.37 & 0.15 & 1.3 \\
\hline 2 & 1.64 & 0.62 & 0.24 & 0.44 \\
\hline 3 & 1.09 & 0.23 & 0.14 & 0.41 \\
\hline
\end{tabular}

The national database for the Netherlands of all storm water data collected over a fifteen-year period was examined [25] and a summary of the data is presented in Table 8 and Table 9. The total number of individual events exceeded 7,600 from more than 60 municipalities over 150 locations. The database was focused on urban areas, segmented in residential areas and commercial zones. Most of the samples were grab samples and were analysed in certified laboratories according to standard methods and standard quality control/assurance procedures. 
Table 8. Concentrations of pollutants in stormwater runoff from residential areas roofs and roads in the Netherlands.

\begin{tabular}{|l|c|c|c|c|c|c|}
\hline & $\begin{array}{c}\mathbf{C u} \\
(\mu \mathrm{g} / \mathbf{l} \\
\end{array}$ & $\begin{array}{c}\mathbf{H g} \\
(\boldsymbol{\mu g} / \mathbf{l} \\
)\end{array}$ & $\begin{array}{c}\mathbf{P b} \\
(\boldsymbol{\mu g} / \mathbf{l} \\
)\end{array}$ & $\begin{array}{c}\mathbf{N i} \\
(\boldsymbol{\mu g} / \mathbf{l} \\
)\end{array}$ & $\begin{array}{c}\mathbf{Z n} \\
(\boldsymbol{\mu g} / \mathbf{l} \\
)\end{array}$ & $\begin{array}{c}\mathbf{P A H 1} \\
\mathbf{0} \\
(\boldsymbol{\mu g} / \mathbf{l})\end{array}$ \\
\hline $\begin{array}{l}\text { Mean } \\
\mathrm{n}\end{array}$ & 19 & 0.05 & 18 & 5.6 & 102 & 0.8 \\
\hline
\end{tabular}

Table 9. Concentrations of pollutants in stormwater runoff from residential areas roofs and roads in the Netherlands (continued).

\begin{tabular}{|l|c|c|c|}
\hline & $\begin{array}{c}\text { BOD } \\
(\mathbf{m g} / \mathbf{l})\end{array}$ & $\begin{array}{c}\text { Suspended } \\
\text { Solids (mg/l) }\end{array}$ & $\begin{array}{c}\text { E. Coli } \\
(\mathbf{m p n} / \mathbf{1 0 0} \mathbf{~ m l})\end{array}$ \\
\hline Mean & 5.7 & 29.9 & $1.9 \times 10^{4}$ \\
\hline Median & 3.1 & 11 & $6.7 \times 10^{3}$ \\
\hline
\end{tabular}

Urban storm water runoff quality from 16 rain events was investigated in a study performed in an old residential district catchment situated in central Paris [26]. The catchment area is densely populated and is $90 \%$ impervious. Samples were taken from three types of land uses, roof cover representing $54.5 \%$ of the area, streets representing $23 \%$, and yard runoff representing $22.5 \%$. Table 10 shows the median EMCs measured for each type of land use runoff.

Table 10. Median EMCs for roof, yard and street runoff.

\begin{tabular}{|l|c|c|c|c|c|c|}
\hline & $\begin{array}{c}\text { SS } \\
(\mathbf{m g} / \mathbf{l})\end{array}$ & $\begin{array}{c}\text { COD } \\
(\mathbf{m g} / \mathbf{l})\end{array}$ & $\begin{array}{c}\text { BODs } \\
(\mathbf{m g} / \mathbf{l})\end{array}$ & $\begin{array}{c}\mathbf{C u} \\
(\boldsymbol{\mu g} / \mathbf{l})\end{array}$ & $\begin{array}{c}\mathbf{P b} \\
(\boldsymbol{\mu g} / \mathbf{l})\end{array}$ & $\begin{array}{c}\mathbf{Z n} \\
(\boldsymbol{\mu g} / \mathbf{l})\end{array}$ \\
\hline $\begin{array}{l}\text { Roof } \\
\text { runoff }\end{array}$ & 29 & 31 & 4 & 37 & 493 & 3422 \\
\hline $\begin{array}{l}\text { Yard } \\
\text { runoff }\end{array}$ & 74 & 95 & 17 & 23 & 107 & 563 \\
\hline $\begin{array}{l}\text { Street } \\
\text { runoff }\end{array}$ & 92.5 & 131 & 36 & 61 & 133 & 550 \\
\hline
\end{tabular}

\section{Methodology}

Due to logistical considerations and an attempt to compare data obtained with an existing, robust international data set, a high-density residential area catchment was chosen for this study. Although in the Romanian land use standard classification there is no high-density residential component, the area where the samples were collected consists of medium and high-rise apartment buildings intermixed with a few low height buildings and singlefamily plots. The area has significant diurnal traffic, being a main thoroughfare between two very busy boulevards. In addition, as elsewhere in the city, the street and adjacent roads are occupied with parked auto vehicles throughout the day. As seen in Fig. 1, the catchment area is highly impermeable, consisting of surfaces of approximately $80 \%$ impervious surfaces.

Grab samples were collected from an area adjacent to a typical catch basin structure of the municipal combined wastewater collection system, that collects runoff from the surrounding impervious surfaces, consisting mostly of road way, sidewalks, and roofs, as shown in Fig. 2. Grab samples are instantaneous discrete samples manually taken within a short period of time, usually less than 15 minutes, and can be collected at any moment during the storm event.

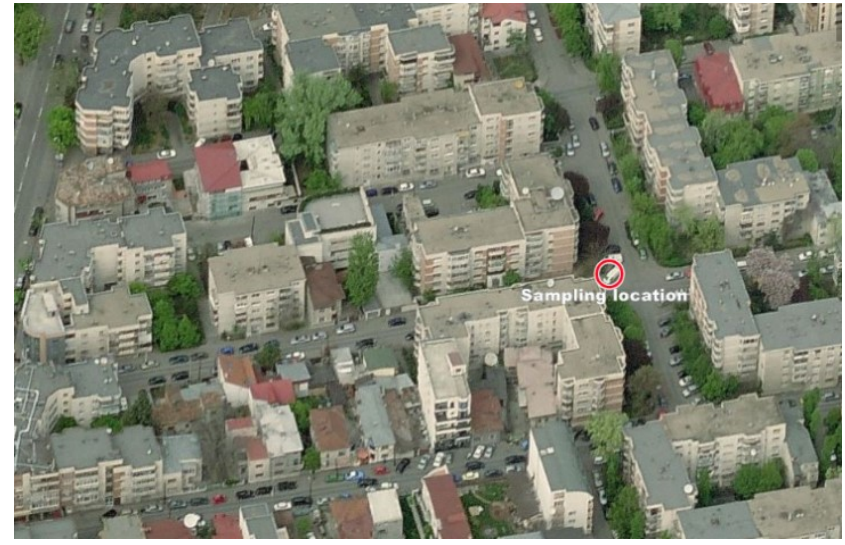

Fig. 1. General sampling location.

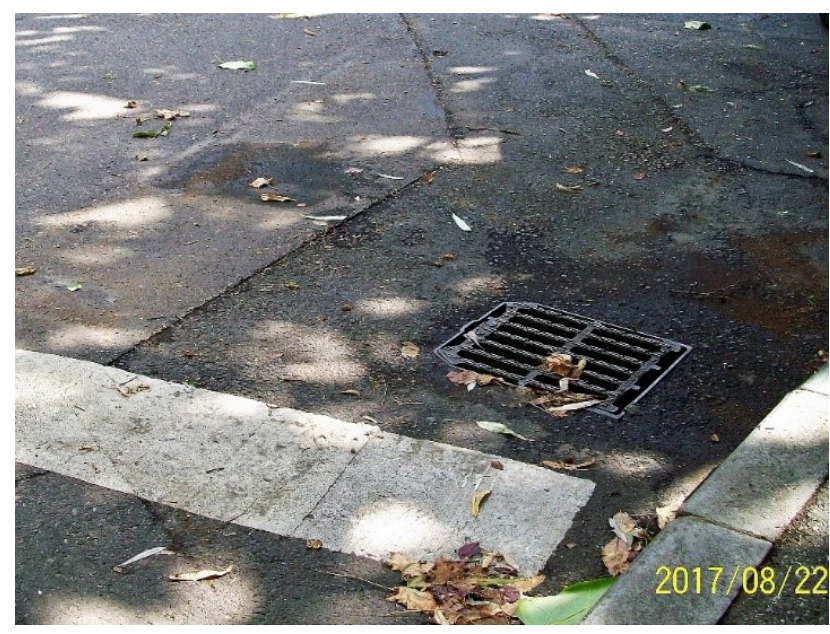

Fig. 2. Sampling location.

Storm water runoff samples were collected from five rain events in accordance with existing guidance [27] and every attempt was made to collect them as early as possible after the precipitation started. For two of the storms, samples were taken within the first 30 minutes from the beginning of the rain, while for the other three, within four hours from the start of rainfall. In addition, the samples were collected with an interceding dry period of at least 72 hours between storm events. Between the first and second sampling event extensive work was performed in the area to install an underground communication cable within the sidewalk surface. Water samples were collected in conformance with standard procedures in clean receptacles obtained from the laboratory performing the analysis. The samples were stored in an ice cooler at $4^{\circ} \mathrm{C}$ temperature and they were delivered to the laboratory for analysis within the recommended period. The sample analysis was performed in an accredited laboratory using European standard methods and detection limits.

The pollutant concentrations were analysed for several water quality parameters including $\mathrm{pH}$, conductivity, oil and grease, heavy metals, nutrients, PAHs and pathogen indicator bacteria. The first sampling event served as a screening method to determine which constituents were present in significant concentrations for further analysis, and consequently, some pollutants were dropped from the subsequent sampling events. Additional sampling for the constituents initially dropped was performed later to 
confirm the assumption made for exclusion. Out of the five rain events, only three were analysed for microorganisms.

\section{Results}

Runoff samples were collected from the location presented in figures above, representative of a high density residential area, during the Summer and Fall season, as shown in Table 11. The pollutant concentration results from grab sampling are shown in Table 12 and Table 13 and a summary of basic statistics for select constituents in Table 14.

Table 11. Sample events.

\begin{tabular}{|c|c|c|c|}
\hline Event & $\begin{array}{c}\text { Constituents } \\
\text { analysed }\end{array}$ & $\begin{array}{c}\text { Antecedent } \\
\text { dry period } \\
\text { (days) }\end{array}$ & $\begin{array}{c}\text { Rainfall } \\
\text { depth } \\
\text { (mm) }\end{array}$ \\
\hline $\begin{array}{c}21 \text { August } \\
2017\end{array}$ & $\begin{array}{l}\text { The entire suite of } \\
\text { physical-chemical } \\
\text { and }\end{array}$ & 23 & 2.03 \\
\hline
\end{tabular}

\begin{tabular}{|c|l|c|c|}
\hline Event & $\begin{array}{c}\text { Constituents } \\
\text { analysed }\end{array}$ & $\begin{array}{c}\text { Antecedent } \\
\text { dry period } \\
\text { (days) }\end{array}$ & $\begin{array}{c}\text { Rainfall } \\
\text { depth } \\
\text { (mm) }\end{array}$ \\
\hline $\begin{array}{c}\text { bacteriological } \\
\text { parameters }\end{array}$ & & 14.99 \\
2017 & $\begin{array}{l}\text { Reduced set of } \\
\text { physical-chemical } \\
\text { parameters }\end{array}$ & 7 & 13.97 \\
\hline 2 & $\begin{array}{l}\text { Reduced set of } \\
\text { physical-chemical } \\
\text { parameters }\end{array}$ & 4 & 23.88 \\
2017 & $\begin{array}{l}\text { Reduced set of } \\
\text { physical-chemical } \\
\text { and } \\
\text { bacteriological } \\
\text { parameters }\end{array}$ & 14 & \\
\hline $\begin{array}{c}\text { October } \\
2017\end{array}$ & $\begin{array}{l}\text { Reduced set of } \\
\text { physical-chemical } \\
\text { and } \\
\text { bacteriological } \\
\text { parameters }\end{array}$ & 7 & 5.08 \\
\hline $\begin{array}{c}\text { November } \\
2017^{1}\end{array}$ & & \\
\hline
\end{tabular}

Table 12. Urban storm water runoff analytical results for select physical-chemical parameters.

\begin{tabular}{|c|c|c|c|c|c|c|}
\hline Parameter & Units & Event 1* & Event $2 * *$ & Event 3* & Event $4 * *$ & Event $5 * *$ \\
\hline $\mathrm{pH}$ & pH Units & 6.5 & 7.2 & 7 & 6.5 & 6.5 \\
\hline Conductivity & $\mu \mathrm{S} / \mathrm{cm}$ & 90 & 239 & 160 & 323 & 97 \\
\hline Total Hardness & $\begin{array}{l}\text { German } \\
\text { degrees }\end{array}$ & 1.7 & 7.35 & 5.09 & - & - \\
\hline Alkalinity & $\mathrm{mval} / \mathrm{l}$ & 0.62 & 1.5 & 0.93 & - & - \\
\hline Ammonium & $\mathrm{mg} / \mathrm{l}$ & 1.7 & 11.25 & 2.42 & 1.34 & 0.41 \\
\hline Nitrates & $\mathrm{mg} / \mathrm{l}$ & 11 & 29.45 & 1.2 & 3.18 & 0.71 \\
\hline Nitrites & $\mathrm{mg} / \mathrm{l}$ & 0.47 & 2.47 & 2.97 & 0.011 & 0.12 \\
\hline $\mathrm{Ca}$ & $\mathrm{mg} / \mathrm{l}$ & 8.11 & - & - & - & - \\
\hline As & $\mu \mathrm{g} / 1$ & $<0.6$ & - & - & - & - \\
\hline $\mathrm{Cd}$ & $\mu \mathrm{g} / 1$ & 0.4 & - & - & - & - \\
\hline $\mathrm{Cu}$ & $\mu \mathrm{g} / 1$ & 23.8 & 79 & 88.5 & - & 12.7 \\
\hline $\mathrm{Ni}$ & $\mu \mathrm{g} / 1$ & 35.9 & - & - & 2.3 & 4.8 \\
\hline $\mathrm{Fe}$ & $\mu \mathrm{g} / 1$ & 244 & - & - & 1.59 & - \\
\hline $\mathrm{Mn}$ & $\mu \mathrm{g} / 1$ & 87.5 & - & - & 25.3 & - \\
\hline $\mathrm{Pb}$ & $\mu \mathrm{g} / 1$ & 0.8 & 0.81 & 0.38 & - & - \\
\hline $\mathrm{Zn}$ & $\mu \mathrm{g} / 1$ & 79.8 & 277 & 196 & 44.1 & 40.9 \\
\hline
\end{tabular}

* Sample taken 30 minutes after the start of the rain

** Sample taken 4 hours after the start of the rain

\section{Conclusions}

The purpose of the study was to ascertain the characteristics of the urban storm water runoff quality from a residential area in Bucharest, Romania, and compare it with the international data for residential urban storm water runoff quality. A summary of the data reviewed is presented in Table 15. Determining the profile of the pollutograph and identifying the constituents of concern may help in selecting the appropriate storm water control measures (SCMs). These SCMs include green infrastructure, nature-based solutions such as green roofs and bioswales, and also other methods such as the new development design to reduce the percentage of impervious surface covers [19]. 
Table 13. Urban storm water runoff analytical results for bacteriological parameters.

\begin{tabular}{|l|c|c|c|c|}
\hline Parameter & Units & $\begin{array}{c}\text { Event } \\
\mathbf{1}^{*}\end{array}$ & $\begin{array}{c}\text { Event } \\
\mathbf{4}^{* *}\end{array}$ & $\begin{array}{c}\text { Event } \\
\mathbf{5}^{* *}\end{array}$ \\
\hline $\begin{array}{l}\text { No. total bact. } \\
\text { that develops at } \\
37^{\circ} \mathrm{C}\end{array}$ & $\mathrm{CFU} / \mathrm{cm}^{3}$ & $51 \times 10^{3}$ & $\begin{array}{c}141 \times \\
10^{8}\end{array}$ & $\begin{array}{c}38 \times \\
10^{7}\end{array}$ \\
\hline $\begin{array}{l}\text { Total coliforms } \\
\text { bacteria }\end{array}$ & $\begin{array}{c}\mathrm{CFU} / 100 \\
\mathrm{~cm}^{3}\end{array}$ & $1 \times 10^{8}$ & $\begin{array}{c}242 \times \\
10^{6}\end{array}$ & $1 \times 10^{6}$ \\
\hline $\begin{array}{l}\text { Escherichia } \\
\text { Coli }\end{array}$ & $\begin{array}{c}\mathrm{CFU} / 100 \\
\mathrm{~cm}^{3}\end{array}$ & $3 \times 10^{4}$ & $2 \times 10^{6}$ & $3 \times 10^{4}$ \\
\hline $\begin{array}{l}\text { Fecal coliforms } \\
\text { bacteria }\end{array}$ & $\begin{array}{c}\mathrm{CFU} / 100 \\
\mathrm{~cm}^{3}\end{array}$ & $27 \times 10^{4}$ & $\begin{array}{c}48 \times \\
10^{5}\end{array}$ & $2 \times 10^{4}$ \\
\hline Enterococci & $\begin{array}{c}\mathrm{CFU} / 100 \\
\mathrm{~cm}^{3}\end{array}$ & $9 \times 10^{6}$ & $7 \times 10^{5}$ & $\begin{array}{c}14 \times \\
10^{3}\end{array}$ \\
\hline Salmonella spp. & $\begin{array}{c}\mathrm{CFU} / 100 \\
\mathrm{~cm}^{3}\end{array}$ & Absent & $\begin{array}{c}\text { Present } \\
* * *\end{array}$ & Absent \\
\hline
\end{tabular}

*Sample taken 30 minutes after the start of the rain

**Sample taken 4 hours after the start of the rain

***Using the automatic Biolog Omnilog bacterial identification system

Table 14. Basic statistics for select parameters.

\begin{tabular}{|l|c|c|c|c|c|}
\hline Parameter & Units & Mean & Median & Min. & Max. \\
\hline $\mathrm{NH}_{4}{ }^{+}$ & $(\mathrm{mg} / \mathrm{l})$ & 3.42 & 1.70 & 0.41 & 11.25 \\
\hline Nitrates & $(\mathrm{mg} / \mathrm{l})$ & 9.11 & 3.18 & 0.71 & 29.45 \\
\hline $\mathrm{Nitrites}$ & $(\mathrm{mg} / \mathrm{l})$ & 1.21 & 0.47 & 0.01 & 2.97 \\
\hline $\mathrm{Cu}$ & $(\mu \mathrm{g} / \mathrm{l})$ & 51.00 & 51.40 & 12.70 & 88.50 \\
\hline $\mathrm{Ni}$ & $(\mu \mathrm{g} / \mathrm{l})$ & 14.33 & 4.80 & 2.30 & 35.90 \\
\hline $\mathrm{Zn}$ & $(\mu \mathrm{g} / \mathrm{l})$ & 127.56 & 79.80 & 40.90 & 277.00 \\
\hline
\end{tabular}

In a previous report, we concluded that uncontrolled urban storm water runoff contains pollutants in concentrations that exceed Romanian and international water quality standards [28]. The groups of constituents of concern, particularly heavy metals, nutrients and pathogens need to be controlled by appropriate SCMs. These results confirm European Commission's concern regarding the fate of combined sewer overflows [3]. Bucharest, as many cities in Europe, is served by a combined sewer system that conveys wastewater and storm water to a treatment plant at the end of the sewer system where the waste is treated before it is discharged into the receiving waters. However, the new approach of separating wastewater and storm sewer systems in new developments, as a preferred method of urban design, may need to consider the potential impact of urban storm water runoff on the quality of receiving waters.

Overall, the results obtained from this research show that the quality of residential urban runoff in Bucharest is comparable with international data. Among the pollutants considered, Zinc, Nickel and Copper concentrations appear to correlate closely with the typical values reported internationally. Lead doesn't appear to be a constituent of concern, because it is detected in very low levels. Similarly, PAHs were not detected, which is unexpected, and may warrant further research. Nutrients concentrations also seem to be in line with the typical values found in the literature. On the other hand, the bacteriological data seems to be at the higher end of the data reported internationally.

Although the method used was through grab sampling, every attempt was made to obtain a sample at the beginning of the rain event to detect a "first flush" phenomenon. In addition, it is hypothesized that taking samples early in a storm event may detect the peak or maximum concentrations [29]. Collecting a sample in the early part of the storm may overestimate the EMC and the total load [29]. It may be assumed, since the catchment area is very small, that the values of the concentrations for samples taken early in the rain event detected peak values for the pollutant concentrations, while samples taken later during the rain, may be closer to the EMC values. The analysis of the data does not indicate a definitely noticeable "first flush" event, however it detected strong signals for a few typical constituents of concern. That may be due to the limited data set and grab sampling that is less accurate than when performed with automatic sampling equipment, with flow weighted composition of aliquots (that is discrete samples collected at equal flow volume intervals). Automatic flow-weighted composite sampling, which can be programmed to collect several hundred samples per storm, is far superior to a series of grab samples [30, 31]. Another important factor in the variability of concentrations may be the time interval between storm events and storm intensities manifested throughout the precipitation period [24, 32].

This is a first investigation of storm water runoff quality in an urban catchment in Romania. It lays the research foundation to conduct a more robust, targeted monitoring study in the future using automatic sampling equipment and accurate rainfall and runoff flow measurements. Additional parameters, such as, Suspended Solids, $\mathrm{BOD}_{5}, \mathrm{COD}$, Phosphorus, and a larger set of PAHs may be included for a broader characterization of the pollutograph. More catchment areas for investigation can be identified and strategically sampling points can be selected to be representative. An improved monitoring program targeting the pollutants of concern may assist the urban planners and water quality engineers in selecting the most effective SCMs, for the control of urban runoff pollution, and their placement, with preference being given to green infrastructure and nature-based solutions advocated by the European Union policies [33-36] and United Nations guidance [37]. 


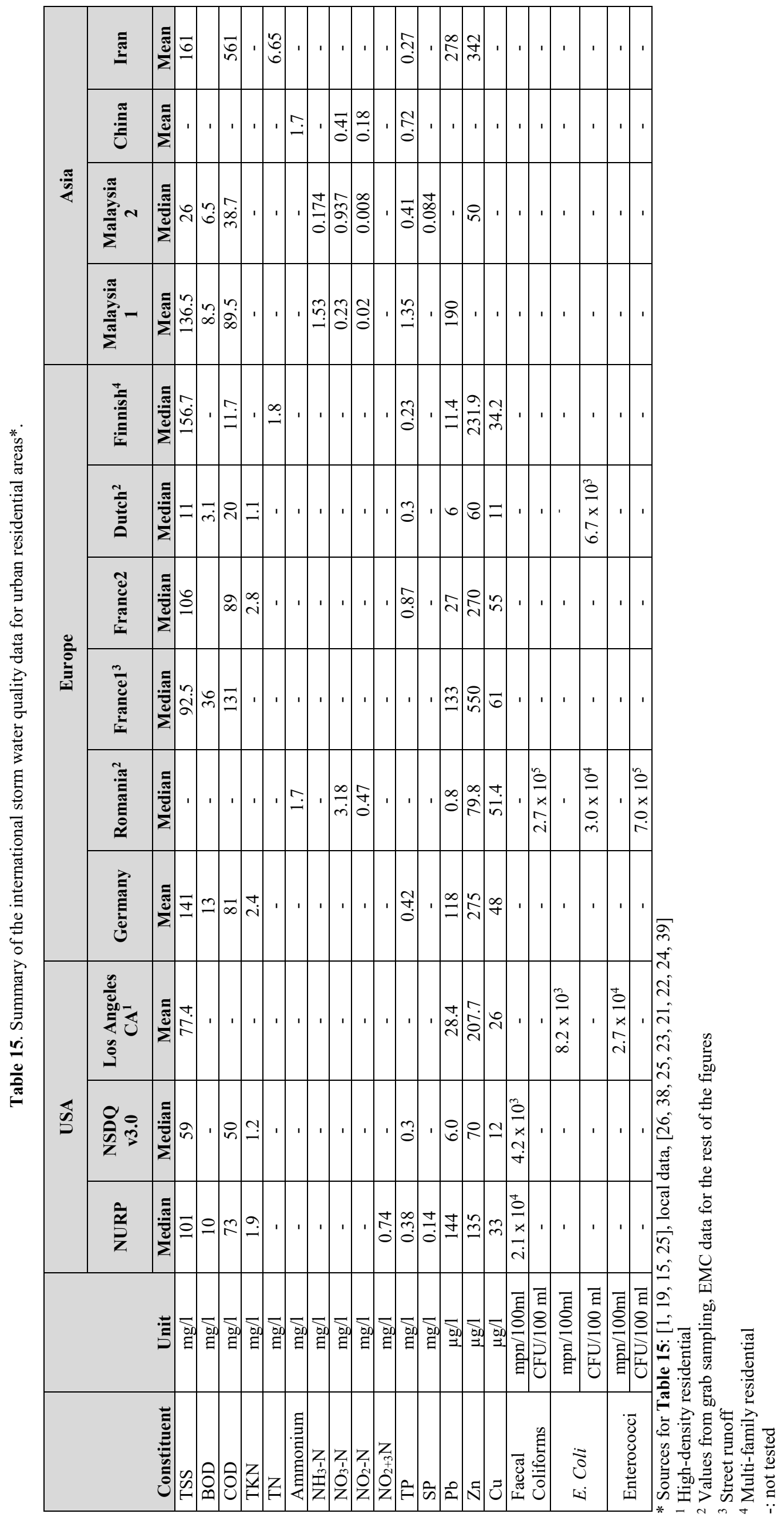




\section{References}

[1] USEPA, Results of the Nationwide Urban Runoff Program - Executive Summary. Water Planning Division, Washington, DC. (1983)

[2] United States Congressional Record - Remarks of Sen. Durenberger, 133 Cong. Rec. 1279 (Jan. 14, 1987)

[3] Milieu Ltd., Assessment of impact of storm water overflows from combined waste water collecting systems on water bodies (including the marine environment) in the 28 EU Member States. European Commission (2016)

[4] USA Today https:/eu.usatoday.com/story/weather/2018/05/28/ell icott-city-flooding-why-1-000-year-rain-eventhappened-again/649502002/ accessed on 06.01.2018

[5] Center for Watershed Protection, Impacts of Impervious Cover on Aquatic Systems - Watershed Protection Research Monograph No. 1. Ellicott City, MD (2003)

[6] C. Bochis, and R.E. Pitt, "Impervious cover variability in urban watersheds", J. Wat. Man. Mod. R236-09. CHI, Inc. DOI: 10.14796/JWMM.R236-09 (2010)

[7] T. Schueler, The Importance of Imperviousness: Watershed Protection Techniques. Center for Watershed Protection 1(3): 100-111. (1994)

[8] C.J. Clausen, G. Warner, D. Civco, M. Hood, Nonpoint Education for Municipal Officials Impervious Surface Research. Final Report, University of Connecticut Dept. Nat. Res. Man. Eng. (2003)

[9] T. Schueler, L. Fraley-McNeal, K. Capiella, "Is Impervious Cover Still Important? Review of Recent Research”, ASCE J. Hydr. Eng. 14:4(309) https://doi.org/10.1061/(ASCE)10840699(2009)14:4(309) (2009)

[10] A. Burant, W. Selbig, E.T. Furlong, C.P. Higgins, "Trace organic contaminants in urban runoff: Associations with urban land-use", J. Env. Pol. 242, B 2068-2077 https://doi.org/10.1016/j.envpol.2018.06.066 (2018)

[11] L. Weerasundara, R.W.K. Amarasekara, D.N. Magana-Arachchi, A.M. Ziyath, D.G. Karunaratne, A. Goonetilleke, A. Vithanage, "Microorganisms and heavy metals associated with atmospheric deposition in a congested urban environment of a developing country: Sri Lanka", J. Sc. Tot. Env. 584 803-812 https://doi.org/10.1016/j.scitotenv.2017.01.121 (2017)

[12] L.D. Sabin, J.H. Lim, K.D. Stolzenbach, K.C. Schiff, "Contribution of trace metals from atmospheric deposition to stormwater runoff in a small impervious urban catchment", J. Wat. Res. 39 3929_ 3937 https://doi.org/10.1016/j.watres.2005.07.003 (2005)
[13] R. Aryal, S. Vigneswaran, J. Kandasamy, R. Naidu, "Urban Stormwater Quality and Treatment", Korean J. Chem. Eng. 27(5), 1343-1359 DOI: 10.1007/s11814-010-0387-0 (2010)

[14] USEPA. Characteristics of Nonpoint Source Urban Runoff and its Effects on Stream Ecosystems. Freshwater Division, Corvallis, OR. (1980)

[15] E.D. Stein, L.L. Tiefenthaler, K.C. Schiff, "Comparison of stormwater pollutant loading by land use type", Annual Report. SCCWRP. (2008)

[16] International Stormwater BMP Database. http://www.bmpdatabase.org/index.htm accessed on 15.05.2018

[17] R.E. Pitt, and A. Maestre, "Stormwater quality as described in the National Stormwater Quality Database (NSQD)", $10^{\text {th }}$ International Conference on Urban Drainage, Copenhagen/Denmark. (2005)

[18] USEPA. https://archive.epa.gov/epa/aboutepa/epatakes-final-step-phaseout-leaded-gasoline.html accessed on 15.05.2018

[19] National Academy of Sciences, Urban Stormwater Management in the United States. National Academies Press, Washington, DC. (2009)

[20] E.D. Stein, L.L. Tiefenthaler, K.C. Schiff, "Sources, Patterns and Mechanisms of Storm Water Pollutant Loading from Watersheds and Land Uses of the Greater Los Angeles Area, California, USA", Technical Report 510, SCCWRP. (2007)

[21] C. Ho, and C.B. Quan, "Runoff Quality and Pollution Loading from a Residential Catchment in Miri, Sarawak", WASET Int. J. Env. Ecol. Eng. Vol:6, No:11 (2012)

[22] M.F. Chow, and Z. Yusop, "Sizing first flush pollutant loading of stormwater runoff in tropical urban catchments", J. Env. Earth Sci. 72:4047-4058 https://doi.org/10.1007/s12665-014-3294-6 (2014)

[23] J. Järveläinen, Land-use based stormwater pollutant load estimation and monitoring system design: Case of Lahti City, Finland. Master's thesis - Aalto University, School of Engineering. (2014)

[24] S. Ballo, M. Liu, L. Hou, J. Chang, "Pollutants in stormwater runoff in Shanghai (China): Implications for management of urban runoff pollution", J. Prog. Nat. Sci. $19873-880$ https://doi.org/10.1016/j.pnsc.2008.07.021 (2009)

[25] F.C. Boogaard, F. van de Ven, J.G. Langeveld, N. van de Gisen, "Stormwater Quality Characteristics in (Dutch) Urban Areas and Performance of Settlement Basins", Challenges 5, 112-122. https://doi.org/10.3390/challe5010112 (2014)

[26] M.C. Gromaire-Mertz, S. Garnaud, A. Gonzalez, G. Chebbo, "Characterisation of Urban Runoff Pollution in Paris", J. Wat. Sci. \& Tech. 39(2):1-8. https://doi.org/10.1016/S0273-1223(99)00002-5 (1999) 
[27] USEPA, Industrial Stormwater Monitoring and Sampling Guide. Washington, DC: USEPA 833-B09-003. (2009)

[28] D. Radulescu, G. Racoviteanu, A.M Pienaru, X. Swamikannu, "Analysis of Urban Residential Storm Water Runoff in Bucharest, Romania", Regional Danube Water Forum-Eastern Europe, International Conference Management and Efficient Water Use Bucharest, (2018)

[29] H. Lee, X. Swamikannu, D. Radulescu, S. Kim, M.K. Stenstrom, "Design of stormwater monitoring programs", J. Wat. Res. 41, 4186- 4196 https://doi.org/10.1016/j.watres.2007.05.016 (2007)

[30] M.K. Stenstrom, and M. Kayhanian, First Flush Phenomenon Characterization. Prepared for California Department of Transportation. CTSWRT-05-73-02.6. (2005)

[31] JS. Ma, JH Kang, M. Kayhanian, M.K. Stenstrom, "Sampling Issues in Urban Runoff Monitoring Programs: Composite versus Grab", ASCE J. Env. Eng. Vol. 135 (3) https://doi.org/10.1061/(ASCE)07339372(2009)135:3(118) (2009)

[32] L.L. Tiefenthaler, K.C. Schiff, S.M. Bay, D.J. Greenstein, "Effect of antecedent dry periods on the accumulation of potential pollutants on parking lot surfaces using simulated rainfall", Annual Report. SCCWRP. (2003)

[33] European Commission, Supporting the Implementation of Green Infrastructure - Final
Report. Directorate-General for the Environment. (2016)

[34] European Union, Development of green infrastructure in EU regions. Nature-based solutions delivering multiple benefits- A policy Brief. Interreg Europe (2017)

[35] European Commission, Nature-Based Solutions \& Re-Naturing Cities - Final Report of the Horizon 2020 Expert Group on 'Nature-Based Solutions and Re-Naturing Cities'. Publications Office of the European Union (2015)

[36] European Commission, EU policy document on Natural Water Retention Measures. Technical Report - 2014 - 082. Directorate-General for the Environment (2014)

[37] WWAP (United Nations World Water Assessment Programme)/UN-Water, The United Nations World Water Development Report 2018: Nature-Based Solutions for Water. UNESCO, Paris (2018)

[38] S. Zgeib, R. Moilleron, G. Chebbo, "Priority pollutants in urban stormwater: Part 1 - Case of separate storm sewers", J. Wat. Res. 46 6683-6692 https://doi.org/10.1016/j.watres.2011.12.012 (2012)

[39] A. Taebi, and R.L. Droste, "Pollution loads in urban runoff and sanitary wastewater", J. Sci. Tot. Env. 327 175-184 https://doi.org/10.1016/j.scitotenv.2003.11.015 (2004) 